\title{
LEADERSHIP DAN ETOS KERJA BERPENGARUH TERHADAP KINERJA
}

\section{Zufrie}

Dosen Tetap Sekolah Tinggi Ilmu Ekonomi Labuhan Batu, Sumatera Utara

Email : zufrieanhal@ rocketmail.com

\begin{abstract}
ABSTRAK:
Dalam dunia usaha atau suatu organisasi dibutuhkan personal yang mempunyai kinerja yang baik. Dengan kinerja yang baik maka tujuan persahaan akan dapat dicapai secara optimal.Untuk meningkatkan kinerja dibutuhkan sebuah etos kerja. Organisasi adalah alat untuk mencapai tujuan yang harus bisa memberikan kejelasan kepada salah seorang, status dalam organisasi baik dari segi ikatan, posisi dan peran. Salah satu upaya untuk meningkatkan kinerja adalah perhatian terhadap leadership dan etos kerja untuk karyawan sebuah perusahaan. Kesediaan untuk bekerja keras dan keinginan untuk mempertahankan keanggotaan, meningkatkan kemampuan organisasi memerlukan leadership yang kuat agar terbangun hubungan interpersonal. Dalam situasi ini sebuah organisasi dibutuhkan leadership, norma dan praktik yang berlaku setiap hari. Leadership dan etos kerja merupakan dua hal yang di perlukan terhadap kualitas kinerja.
\end{abstract}

Kata kunci: leadership, etos kerja dan kinerja

\section{PENDAHULUAN}

Leadership atau Kepemimpinan ditujukan untuk meningkatkan kinerja pegawai dengan mempermudah pekerjaan dengan memberikan pelatihan, komunikasi, memberikan perhatian secara personal kepada bawahan dan motivasi. Dengan cara-cara demikian pemimpin telah memberikan pengaruh yang positif, memberi contoh sebagai suri tauladan yang baik sehingga mendorong bawahan untuk bekerja lebih baik.

Etos kerja dapat meningkatkan kinerja sebuah organisasi atau instansi, seorang pemimpin harus dapat memperhatikan dan menilai serta mendorong supaya etos kerja pegawai meningkat. Etos juga merupakan dasar utama bagi upaya meningkatkan kualitas sumber daya manusia, baik di tingkat individu maupun secara tim .

Kinerja sangat penting untuk diperhatikan oleh setiap organisasi, kinerja pegawai yang menjadi prioritas utama yang harus diperhatikan, karena pegawai merupakan faktor utama dalam proses kerja yang pada gilirannya menjadikan kinerja organisasi harus dipastikan secara keseluruhan berlangsung secara baik. 


\section{LEADERSHIP}

\section{Pengertian Leadership (Kepemimpinan)}

Martinis Yamin dan Maisah (2010:74) kepemimpinan adalah sebagai suatu grup proses yang dilakukan oleh seseorang dalam mengelola dan menginspirasikan sejumlah pekerjaan untuk mencapai tujuan organisasi melalui aplikasi teknik - teknik manajemen. Miftah Thoha (2010 : 9) kepemimpinan adalah kegiatan untuk mempengaruhi perilaku orang lain atau seni mempengaruhi orang baik secara individu maupun kelompok.

Robbins (2011:410) kepemimpinan adalah Kemampua untuk mempengaruhi suatu kelompok untuk pencapaian suatu visi dan tujuan.Sedangkan menurut Terry (2010:153) Kepemimpinan merupakan Hubungan yang ada dalam diri seseorang atau pemimpin,mempengaruihi orang lain untuk nekerja secara sadar dalam hubungan tugas dalam mencapai tujuan yang di inginkan.

Nawawi (2015:155 ) Mengatakan bahwa kepemimpinan adalah bagian dari manajemen,tetapi tidak semuanya misalnya para manajer perlu membuat rencana dan mengorganisir,tetapi yang diminta pemimpin hanyalah agar mereka mempengaruhi orang lain untuk ikut.

Berdasarkan beberapa pengertian di atas tentang kepemimpinan dapat disimpulkan bahwasannya kepemimpinan adalah seni atau proses untuk Memotivasi Kerja, mempengaruhi, mengkoordinasi, memberikan dorongan, perintah dan bimbingan terhadap individu atau kelompok untuk mencapai tujuan dan sasaran yang telah ditetapkan dengan kemauan dan antusias tanpa adanya paksaan.

\section{Tipe -Tipe Kepemimpinan}

Menurut Terry (2010 : 132). mengemukakan bahwasanya tipe kepemimpinan terbagi menjadi 6 bagian yaitu :

1. Tipe kepemimpinan Pribadi ( Personal Leadership ) dalam sistem kepemimpinan ini, segala sesuatu tindakan dilakukan dengan mengadakan kontak pribadi, petunjuk ini dilakukan secara lisan atau secara langsung dilakukan secara pribadi oleh pemimpin yang bersangkutan.

2. Tipe Kepemimpina Non Pribadi (Non Personal Leadership) Segala sesuatu kebijaksanaan yang dilaksanakan melalui bawahan - bawahan atau non media pribadi baik rencana atau perintah pengawasan.

3. Tipe Kepemimpinan Otoriter (Authoritorian Leadership). Pemimpin otoriter biasanya bekerja keras, sungguh-sungguh, teliti dan tertib ia bekerja menurut peraturan-peraturan yang berlaku secara ketat dan Intruksinya harus ditaati.

4. Tipe Kepemimpinan Demokratis (democratis Leadership). Pemimpin yang demokratis menganggap dirinya sebagai bagian dari kelompoknya dan bersama - sama dengan kelompoknya dalam berusaha bertanggung jawab tentang terlaksananya tujuan bersama 
agar setiap anggota turut bertanggung jawab, maka setiap anggota ikut serta dalam setiap kegiatan, perencanaan, penyelenggaraan, pengawasan, dan penilaian. Setiap anggota di anggap sebagai potensi yang berharga dalam usaha pencapaian tujuan .

5. Tipe Kepemimpinan Paternalistik, Kepemimpinan ini didirikan oleh suatu pengaruh yang bersifat kebapakan dalam hubungan pemimpin dan kelompok. Tujuannya adalah untuk melindungi dan untuk memberikan arah seperti halnya seorang bapak kepada anaknya.

6. Tipe Kepemimpinan menurut Bakat (Indogenious Leadership). Biasanya Timbul dari kelompok orang - orang yang informal dimana mungkin mereka berlatih dengan adanya sistem kompetisi, sehingga bisa menimbulkan daya saing dari kelompok yang bersangkutan dan biasanya akan muncul pemimpin akan mucul yang mempunyai kelemahan diantara yang ada dalam kelompok tersebut .

\section{Fungsi-Fungsi Kepemimpinan}

Menurut Handoko (2008) Terdapat dua fungsi utama dalam kepemimpinan yakni:

1. Fungsi yang berhubungan dengan tugas (taksrelated) atau pemecahan masalah. Fungsi ini menyangkut pemberian saran penyelesaian, informasi dan pendapat.

2. Fungsi pemeliharaan kelompok (group maintenance) atau sosial. Segala sesuatu yang dapat membantu kelompok berjalan lancar, persetujuan dengan kelompok lain, penengah perbedaan pendapat, dan sebagainya.

\section{ETOS KERJA}

\section{Pengertian Etos Kerja}

Etos kerja seseorang erat kaitannya dengan kepribadian, perilaku dan karakter. Setiap orang memiliki internal being yang merupakan siapa dia. Kemudian intenal being menetapkan respon atau reaksi terhadap tuntutan eksternal. Respon internal being terhadap tuntutan eksternal dunia kerja menetapkan etos kerja seseorang (Siregar, 2000).

Etos berasal dari bahasa yunani ethos yakni karakter, cara hidup, kebiasaan seseorang, motivasi atau tujuan moral seseorang serta pandangan dunia mereka, yakni gambaran, cara bertindak ataupun gagasan yang paling komprehensif mengenai tatanan. Dengan kata lain etos adalah aspek evaluatif sebagai sikap mendasar terhadap diri dan dunia mereka yang direfleksikan dalam kehidupannya (Khasanah, 2004:8).

Etos kerja yang tinggi seyogyanya dimiliki setiap pegawai atau pemimpin di suatu lembaga, ini sangat membutuhkan kerja keras dan komitmen yang tinggi dari setiap pegawai, kalau tidak organisasi akan sulit berkembang, dan memenangkan persaingan dalam merebut pangsa pasarnya. 
Tasmara, (2002) menjabarkan etos kerja yang seharusnya dimiliki oleh seorang pegawai adalah totalitas kepribadian dirinya serta caranya mengekspresikan, memandang, meyakini dan memberikan makna ada sesuatu, yang mendorong dirinya untuk bertindak dan meraih amal yang optimal sehingga pola hubungan antara manusia dengan dirinya dan antara manusia dengan makhluk lainnya dapat terjalin dengan baik. Etos kerja berhubungan dengan beberapa hal penting seperti:

1. Orientasi ke masa depan, yaitu segala sesuatu direncanakan dengan baik, baik waktu, kondisi untuk ke depan agar lebih baik dari kemarin.

2. Menghargai waktu dengan adanya disiplin waktu merupakan hal yang sangat penting guna efesien dan efektivitas bekerja.

3. Tanggung jawab, yaitu memberikan asumsi bahwa pekerjaan yang dilakukan merupakan sesuatu yang harus dikerjakan dengan ketekunan dan kesungguhan.

4. Hemat dan sederhana, yaitu sesuatu yang berbeda dengan hidup boros, sehingga bagaimana pengeluaran itu bermanfaat untuk kedepan.

5. Persaingan sehat, yaitu dengan memacu diri agar pekerjaan yang dilakukan tidak mudah patah semangat dan menambah kreativitas diri.

\section{Faktor-Faktor Terbentuknya Etos Kerja}

1. Agama

Sejak Weber menelurkan karya tulis The Protestant Ethic and the Spiritof Capitalism (1958), berbagai studi tentang Etos Kerja berbasis agama sudah banyak dilakukan dengan hasil yang secara umum mengkonfirmasikan adanya korelasi positif antara sebuah sistem kepercayaan tertentu dan kemajuan ekonomi, kemakmuran, dan modernitas (Sinamo, 2005). Menurut Rosmiani (1996) Etos Kerja terkait dengan sikap mental, tekad, disiplin dan semangat kerja. Sikap ini dibentuk oleh sistem orientasi nilai-nilai budaya, yang sebagian bersumber dari agama atau sistem kepercayaan/paham teologi tradisional.

\section{Budaya}

Kualitas Etos Kerja ini ditentukan oleh sistem orientasi nilai budaya masyarakat yang bersangkutan. Masyarakat yang memiliki sistem nilai budaya maju akan memiliki Etos Kerja yang tinggi dan sebaliknya, masyarakat yang memiliki sistem nilai budaya yang konservatif akan memiliki Etos Kerja yang rendah, bahkan bisa sama sekali tidak memiliki Etos Kerja.

\section{Sosial politik}

Soewarso, dkk., (1995) menemukan bahwa tinggi rendahnya etos kerja suatu masyarakat dipengaruhi oleh ada atau tidaknya struktur politik yang mendorong masyarakat untuk bekerja keras dan dapat menikmati hasil kerja keras mereka dengan penuh. Etos kerja harus dimulai dengan kesadaran akan pentingnya arti tanggung jawab kepada masa depan bangsa dan negara.

\section{Kondisi Lingkungan/Geografis}

Etos kerja dapat muncul dikarenakan faktor kondisi geografis. Lingkungan alam yang mendukung mempengaruhi manusia yang 
berada di dalamnya melakukan usaha untuk dapat mengelola dan mengambil manfaat, dan bahkan dapat mengundang pendatang untuk turut mencari penghidupan di lingkungan tersebut.

\section{Pendidikan}

Etos kerja tidak dapat dipisahkan dengan kualitas sumber daya manusia. Peningkatan sumber daya manusia akan membuat seseorang mempunyai Etos Kerja keras. Meningkatnya kualitas penduduk dapat tercapai apabila ada pendidikan yang merata dan bermutu, disertai dengan peningkatan dan perluasan pendidikan, keahlian dan keterampilan, sehingga semakin meningkat pula aktivitas dan produktivitas masyarakat sebagai pelaku ekonomi.

\section{Struktur Ekonomi}

Menurut Soewarso, Rahardjo, Subagyo, dan Utomo (1995) disimpulkan juga bahwa tinggi rendahnya Etos Kerja suatu masyarakat dipengaruhi oleh ada atau tidaknya struktur ekonomi, yang mampu memberikan insentif bagi anggota masyarakat untuk bekerja keras dan menikmati hasil kerja keras mereka dengan penuh.

\section{Motivasi intrinsik individu}

Anoraga (1992) mengatakan bahwa Individu yang akan memiliki Etos Kerja yang tinggi adalah individu yang bermotivasi tinggi. Etos Kerja merupakan suatu pandangan dan sikap, yang tentunya didasari oleh nilai-nilai yang diyakini seseorang. Keyakinan inilah yang menjadi suatu motivasi kerja. Maka Etos Kerja juga dipengaruhi oleh motivasi seseorang.

\section{Indikator Etos Kerja}

Salamun dkk. (1995) mengemukakan indikator-indikator yang dapat digunakan untuk mengukur etos kerja diantaranya: "kerja keras, disiplin, jujur dan tanggung jawab, rajin dan tekun".

1. Kerja keras

Kerja keras ialah bahwa di dalam bekerja mempunyai sifat mabuk kerja untuk dapat mencapai sasaran yang ingin dicapai. Dapat memanfaatkan waktu yang optimal sehingga kadangkadang tidak mengenal waktu, jarak dan kesulitan yang dihadapi.

2. Disiplin

Disiplin sebagai suatu sikap menghormati, menghargai patuh dan taat terhadap peraturan-peraturan yang berlaku baik yang tertulis maupun yang tidak tertulis serta sanggup menjalankannya dan tidak mengelak menerima sanksi-sanksi apabila ia melanggar tugas dan wewenang yang diberikan kepadanya.

3. Jujur

Kejujuran yaitu kesanggupan seorang karyawan dalam menjalankan pekerjaannya sesuai dengan aturan yang sudah ditentukan.

4. Tanggung jawab

Tanggung jawab yaitu memberikan asumsi bahwa pekerjaan yang dilakukan merupakan sesuatu yang harus dikerjakan dengan ketekunan dan kesungguhan. 
5. Rajin

Terciptanya kebiasaan pribadi karyawan untuk menjaga dan meningkatkan apa yang sudah dicapai. Rajin di tempat kerja berarti pengembangan kebiasaan positif di tempat kerja. Apa yang sudah baik harus selalu dalam keadaan prima setiap saat.

6. Tekun

Tekun berarti rajin, keras hati, dan bersungguh-sungguh (bekerja, belajar, berusaha, dsb). Orang yang tekun adalah orang yang bekerja secara teratur, mampu menahan rasa bosan/jemu, dan mau belajar dari kesalahan (orang lain maupun dirinya) di masa lalu agar tidak terulang kembali.

Bagi individu atau kelompok masyarakat yang memiliki etos kerja yang rendah, maka akan ditunjukkan ciri-ciri yang sebaliknya (Kusnan, 2004), yaitu;

1. Kerja dirasakan sebagai suatu hal yang membebani diri,

2. Kurang dan bahkan tidak menghargai hasil kerja manusia,

3. Kerja dipandang sebagai suatu penghambat dalam memperoleh kesenangan,

4. Kerja dilakukan sebagai bentuk keterpaksaan,

5. Kerja dihayati hanya sebagai bentuk rutinitas hidup.

\section{Efek Etos Kerja}

Apabila dikaitkan dengan situasi kehidupan manusia yang sedang "membangun", maka etos kerja yang tinggi akan dijadikan sebagai prasyarat yang mutlak, yang harus ditumbuhkan dalam kehidupan itu. Karena hal itu akan membuka pandangan dan sikap kepada manusianya untuk menilai tinggi terhadap kerja keras dan sungguh-sungguh, sehingga dapat mengikis sikap kerja yang asalasalan, tidak berorientasi terhadap mutu atau kualitas kerja yang semestinya (Cohen, 2002).

\section{KINERJA}

\section{Pengertian Kinerja}

Kinerja menurut Kamus Besar Bahasa Indonesia adalah sesuatu yang hendak dicapai, prestasi yang diperlihatkan dan kemampuan kerja.

Secara umum, kinerja adalah hasil kerja yang dicapai oleh seseorang pegawai dalam melaksanakan tugas yang dibebankan kepadanya. Kinerja merupakan prestasi kerja yang dihasilkan oleh pegawai sesuai dengan peran dan tugas yang diembannya dalam instansi. Lebih lanjut, kinerja merupakan tindakan atau pelaksanaan tugas yang dapat diukur dalam ukuran kinerja secara umum meliputi: kualitas kerja, kuantitas kerja, pengetahuan tentang pekerjaan, dan perencanaan kerja (Sutisna, 2012).

Kinerja didefinisikan sebagai kontribusi terhadap hasil akhir organisasi dalam kaitannya dengan sumber yang dihabiskan (Bain, 2012 dalam McNeeseSmith, 2016:09) dan harus diukur dengan indikator kualitatif dan kuantitatif (Belcher, 2017; Cohen 2010 dalam McNeese-Smith, 2016:13).

Kinerja merupakan kondisi yang harus diketahui dan diinformasikan kepada pihak-pihak tertentu untuk mengetahui tingkat pencapaian hasil suatu 
instansi dihubungkan dengan visi yang diemban suatu organisasi serta mengetahui dampak positif dan negatif suatu kebijakan operasional yang diambil. Dengan adanya informasi mengenai kinerja suatu instansi pemerintah, akan dapat diambil tindakan yang diperlukan seperti koreksi atas kebijakan, meluruskan kegiatankegiatan utama, dan tugas pokok instansi, bahan untuk perencanaan, menentukan tingkat keberhasilan instansi untuk memutuskan suatu tindakan, dan lain-lain. Maka pengembangan instrumen dilakukan untuk menilai persepsi pekerjaan akan kinerja diri mereka sendiri dalam kaitannya dengan item-item seperti out put, pencapaian tujuan, pemenuhan deadline, penggunaan jam kerja dan ijin sakit (Sukarno, 2012:09).

Kinerja dipergunakan manajemen untuk melakukan penilaian secara periodik mengenai efektivitas operasional suatu oganisasi dan pegawai berdasarkan sasaran, standar dan kriteria yang telah ditetapkan sebelumnya.

\section{Indikator Kinerja}

Dengan kinerja, organisasi dan manajemen dapat mengetahui sejauh mana keberhasilan dan kegagalan pegawainya dalam menjalankan amanah yang diterima. Bass dan Avolio (2016:45) menjelaskan bahwa dalam organisasi formal, kinerja pegawai secara individual atau kelompok tergantung pada usaha mereka dan arah serta kompetensi dan motivasi untuk menunjukkan performansi sesuai yang diharapkan untuk mencapai sasaran berdasarkan posisi mereka di dalam sistem (Alimuddin, 2012:12). Untuk dapat mengetahui kinerja seseorang atau organisasi, perlu diadakan pengukuran kinerja. Untuk dapat mengetahui kinerja seseorang atau organisasi, perlu diadakan pengukuran kinerja.

Menurut Stout (BPKP, 2014:09), pengukuran kinerja merupakan proses mencatat dan mengukur pencapaian pelaksanaan kegiatan dalam arah pencapaian misi (mission accomplishment) melalui hasilhasil yang ditampilkan berupa produk, jasa ataupun suatu proses. Maksudnya setiap kegiatan organisasi harus dapat diukur dan dinyatakan keterkaitannya dengan pencapaian arah organisasi di masa yang akan datang yang dinyatakan dengan pencapaian visi dan misi organisasi. Produk dan jasa yang dihasilkan akan kurang berarti apabila tidak ada kontribusinya terhadap pencapaian visi dan misi organisasi.

Melalui pengukuran kinerja diharapkan pola kerja dan pelaksanaan tugas pembangunan dan tugas umum pemerintahan akan terlaksana secara efesien dan efektif dalam mewujudkan tujuan nasional.

\section{Kegunaan Pengukuran Kinerja}

Pengukuran kinerja pegawai akan dapat berguna untuk:

1. Mendorong orang agar berperilaku positif atau memperbaiki tindakan mereka yang berada di bawah standar kinerja,

2. Sebagai bahan penilaian bagi pihak pimpinan apakah mereka telah bekerja dengan baik, dan

3. Memberikan dasar yang kuat bagi pembuatan kebijakan untuk peningkatan organisasi (BPKP, 2010:18).

Dalam pengukuran kinerja (performance measurement) organisasi hendaknya dapat menentukan aspek-aspek apa saja yang menjadi topik pengukurannya.

Ketiga indikator pengukuran kinerja tersebut akan digunakan sebagai acuan dalam mengukur kinerja pegawai. Kinerja pegawai mengacu pada mutu pekerjaan yang dilakukan oleh pegawai didalam implementasi mereka melayani program sosial. 
Memfokuskan pada asumsi mutu bahwa perilaku beberapa orang yang lain lebih pandai daripada yang lainnya dan dapat diidentifikasi, digambarkan, dan terukur.

\section{Aspek Kinerja}

Aspek dalam kinerja pegawai adalah sebagai berikut:

a. Proaktif dalam pendekatan pekerjaan

b. Bermanfaat dari pengawasan

c. Merasa terikat dalam melayani klien

d. Berhubungan baik dengan staf lain

e. menunjukkan ketrampilan dan pengetahuan inti bekerja aktivitas

f. Menunjukkan kebiasaan bekerja yang baik

g. Mempunyai sikap positif dalam pekerjaan

Standar atau kriteria yang telah ditetapkan perusahaan. Pengelolaan untuk mencapai kinerja pegawai yang sangat tinggi terutama untuk meningkatkan kinerja perusahaan secara keseluruhan. Faktor-faktor yang mempengaruhi kinerja pegawai meliputi strategi organisasi, (nilai tujuan jangka pendek dan jangka panjang, budaya organisasi dan kondisi ekonomi) dan atribut individual antara lain kemampuan dan ketrampilan. Kinerja bisa meningkatkan kepuasan para pegawai dalam organisasi dengan kinerja tinggi daripada organisasi dengan kinerja rendah (Ostroff, 2012:17).

\section{LEADERSHIP DAN ETOS KERJA BERPENGARUH TERHADAP KINERJA}

Keberhasilan suatu organisasi dipengaruhi oleh kinerja (job performance) pegawai, untuk itu setiap instansi atau perusahaan akan berusaha meningkatkan kinerja pegawainya dalam mencapai tujuan organisasi yang telah ditetapkan. Kinerja pegawai dapat dipengaruhi oleh dua faktor yakni Leadership dan etos kerja. Seorang karyawan yang memiliki etos kerja yang tinggi menggambarkan semangat kerja yang tinggi pula, dan pimpinan yang memiliki kepemimpinan yang baik akan cenderung memiliki kinerja yang lebih baik/tinggi. Kepimpinan dan Etos kerja sangat diperlukan agar dapat melaksanakan program-program kerjanya untuk mencapai sasaran yang telah ditetapkan. Apabila karyawan tersebut memiliki etos kerja dan disiplin kerja yang tinggi, maka akan membantu peningkatan kinerja pegawai.

Dalam suatu organisasi fungsi dan peran pemimpin dalam mendorong pembentukan organisasi yang baik diharapkan menjadi paling dominan. Pada era globalisasi kepemimpinan yang dibutuhkan adalah yang memiliki nilai kompetensi yang tinggi dan kompetensi itu bisa diperoleh jika pimpinan tersebut telah memiliki pengalaman dan ilmu pengetahuan yang maksimal.

Seorang pemimpin memiliki pengaruh besar dalam mendorong peningkatan kinerja para pegawai. Peningkatan kualitas kinerja bawahan memiliki pengaruh pada penciptaan kualitas kerja sesuai dengan pengharapan, yang pada gilirannya pengguna produk atau jasa dan stakeholder merasa puas atas hasil kinerja perusahaan dan berdampak pada meningkatnya perolehan keuntungan.

Seorang pemimpin harus bisa mengarahkan bawahannya untuk memiliki kompetensi dalam bekerja. Pemimpin harus bisa melihat perbedaan antara karyawan yang memiliki kompetensi dan yang rendah nilai kompetensinya. Untuk 
itu setiap pemimpin bukan hanya dituntut untuk mampu bekerja secara maksimal namun juga mengerti dimana permasalahan yang dimiliki oleh setiap karyawan. Termasuk permasalahan dalam mengembangkan bakat yang dimiliki oleh seorang karyawan. Dengan memahami bakat dan keahlian dengan kesesuaiannya adalah dengan menempatkan karyawan tesebut sesuai dengan keahliannya seperti konsep "the right man on the raight place."

Pemimpin memiliki peran besar dalam mendampingi untuk mewujudkan karyawan yang memiliki kompetensi, termasuk menerapkan konsep kompetisi yang bersifat dinamis, artinya membangun persaingan namun tetap dalam konteks yang fair dan positif. Dengan adanya persaingan mampu memberi dan membentuk kondisi kerja yang mengutamakan kepentingan perusahaan dari pada kepentingan pribadi.

Etos kerja yang baik dalam instansi dapat membantu karyawan untuk memahami bagaimana cara mereka bekerja menjalankan tugasnya. Etos kerja merupakan suatu perasaan, pembicaraan serta tindakan manusia yang bekerja di dalam instansi, jadi dapat dikatakan bahwa segala sesuatu yang ada di dalam instansi termasuk di dalamnya cara berfikir, bersikap dan bertingkah laku dipengaruhi oleh etos kerja yang ada di instansi.

Etos kerja yang tinggi akan dijadikan prasyarat yang mutlak, yang harus ditumbuhkan dalam kehidupan ini khususnya penyesuaian karyawan dengan tempat dan rekan kerja. Karena hal itu akan membuka pandangan dan sikap menyesuaikan dengan manusianya untuk menilai tinggi terhadap kerja keras dan sungguh-sungguh, sehingga dapat mengikis sikap kerja yang asal-asalan, tidak berorientasi terhadap mutu atau kualitas kerja yang semestinya.

Dengan menerapkan sikap dapat menyesuaiakan diri dan kepribadian tersebut maka seorang karyawan dapat mencapai hasil kerja yang optimal dan juga kinerja karyawan tersebut akan meningkat. Hasil ini menunjukkan bahwa suatu etos kerja dapat membantu dalam memunculkan dan juga dapat meningkatkan kinerja setiap karyawan sehingga mereka dapat bekerja secara optimal dan apa yang menjadi tujuan instansi dapat tercapai.

Kemampuan pegawai dalam memahami pentingnya etos kerja yang tinggi seyogyanya harus dimiliki oleh setiap pegewai karena setiap organisasi atau perusahaan sangat membutuhkan kerja keras dan komitmen yang tinggi setiap pegawai. Setiap organisasi yang selalu ingin maju, akan melibatkan anggota untuk kinerjanya, diantaranya setiap organisasi harus memiliki etos kerja. Etos kerja yang dimiliki oleh seseorang atau kelompok masyarakat, akan menjadi sumber motivasi bagi perbuatannya, sehingga dapat meningkatkan kinerja pegawai.

Berdasarkan penjelasan di atas, dapat dikatakan bahwa leadership dan etos kerja dapat meningkatkan kinerja karyawan karena dengan leadership yang kuat dan etos kerja yang tinggi maka seorang karyawan akan melaksanakan tugas atau pekerjaannya dengan tertib dan lancar sehingga hasil kerjanya akan meningkat serta akan berdampak pula pada tujuan perusahaan yang dapat dicapai secara optimal.

\section{KESIMPULAN}


Kinerja pegawai dapat dipengaruhi oleh dua faktor yakni leadership dan etos kerja. Seorang karyawan yang memiliki etos kerja yang tinggi menggambarkan semangat kerja yang tinggi pula, dan leadership yang kuat mempengaruhi kinerja. Apabila dikaitkan dengan situasi kehidupan manusia yang sedang membangun, maka etos kerja yang tinggi akan dijadikan sebagai persyaratan yang mutlak, yang ditumbuhkan dalam kehidupan. Karena hal itu akan membuka pandangan dan sikap kepada manusianya untuk menilai tinggi terhadap kerja keras dan sungguh-sungguh, sehingga dapat mengikis sikap kerja yang asal-asalan. Sementara itu, kepemimpinan yang efektif mampu memotivasi dan mendorong karyawan untuk senantiasa meningkatkan kinerjanya.

\section{SARAN}

Adapun saran untuk diagendakan penelitian kuantitatif dimasa yang akan datang yaitu dapat mengambil sampel dari berbagai perusahaan. Hal ini dimaksudkan untuk menguji konsistensi hasil penelitian antara penelitian kualitatatif ini dengan penelitian yang berbeda. Misalnya bagi peneliti berikutnya dapat mengambil objek penelitian tidak hanya sebatas pada perusahaan melainkan dapat menguji pada berbagai organisasi yang ada.

\section{DAFTAR PUSTAKA}

Alimuddin. 2002. Pengukuran Kinerja. Jakarta: PT. Raja Grafindo Persada. Anoraga, Panji. 1992. Psikologi Kerja. Jakarta: Penerbit PT. Rineka Cipta.

Bass dan Avolio. 2006. Organisasi Formal Kinerja Pegawai. Bandung: Yrama Widya.

Bain. 2002 dalam McNeese- Smith, 2006. Kinerja Sebagai Kontribusi. Jakarta: PT. Raja Grafindo Persada.

Khasanah, Uswatun. 2004. Etos Kerja Sarana Menuju Puncak Prestasi. Yogyakarta: Harapan Utama.

Kusnan, A., \& Airlangga, U. 2004. Analisis Sikap Iklim Organisasi, Etos Kerja Dan Disiplin Kerja dalam Menentukan Efektivitas Kinerja Organisasi di GarnisunTetap III. Jurnal Ilmiah Bisnis dan Ekonomi ASIA Vol, 4(2). Surabaya. Malang.

Nawawi, 2015,Manajemen Sumber Daya Manusia,Universitas Gadjah Mada,Yogyakarta

Ostroff. 2002. Pengukuran Kinerja. Jakarta: PT. Raja Grafindo Persada.

Robbins SP, dan Judge. 2011.Perilaku Organisasi, Salemba Empat, Jakarta

Salamun, Sumardi, Sadilah, Emiliana, Sumintarsih, Sudijono, dan Suhartinah. 1995. Persepsi Tentang Etos Kerja: Kaitannya Dengan Nilai Budaya Masyarakat Daerah Istimewa Yogyakarta. Yogyakarta: Departemen Pendidikan Dan Kebudayaan RI.

Siregar. 2000. Definisi Etos Kerja. Jurnal (online) http://jurnal-sdm. com/2010/10/etos-kerja-definisi-fungsi-dan-cara.html (diakses tanggal 21 Desember 2015).

Sukarno. 2002. Kinerja Menurut Kamus Besar Bahasa Indonesia. Bandung: Satu Nusa. 
Sutisna, Entis. 2012. Etos Kerja dan Budaya Organisasi Terhadap Kinerja Karyawan Jurnal e-lib UNIKOM. Bandung. Vol 5. Hal 12-24.

Tasmara, Toto. 2002. Membangun Etos Kerja Islam. Jakarta: Gema Insani Pers.

Terry, George dan Leslie W. Rue. 2010. Dasar-Dasar Manajemen. Cetakan kesebelas. Jakarta: PT Bumi Aksara

Yamin, Martinis \& Maisah, (2010).Standarisasi kinerja guru. Jakarta: GP Press. 